\title{
Skin microbes on frogs prevent morbidity and mortality caused by a lethal skin fungus
}

\author{
Reid N Harris ${ }^{1}$, Robert M Brucker ${ }^{2}$, Jenifer B Walke ${ }^{3}$, Matthew H Becker ${ }^{1}$, \\ Christian R Schwantes ${ }^{4}$, Devon C Flaherty ${ }^{4}$, Brianna A Lam ${ }^{1}$, Douglas C Woodhams ${ }^{5}$, \\ Cheryl J Briggs ${ }^{6}$, Vance T Vredenburg7 and Kevin PC Minbiole ${ }^{4}$ \\ ${ }^{1}$ Department of Biology, James Madison University, MSC 7801, Harrisonburg, VA, USA; ${ }^{2}$ Department of \\ Microbiology and Immunology, Vanderbilt University, Nashville, TN, USA; ${ }^{3}$ Department of Biological \\ Sciences, Virginia Tech, MC 0406, Blacksburg, VA, USA $;{ }^{4}$ Department of Chemistry and Biochemistry, James \\ Madison University, MSC 4501, Harrisonburg, VA, USA; ${ }^{5}$ Zoological Institute, University of Zurich, Zurich, \\ Switzerland; ${ }^{6}$ Department of Ecology, Evolution and Marine Biology, University of California, Santa Barbara, \\ CA, USA and ${ }^{7}$ Department of Biology, San Francisco State University, San Francisco, CA, USA
}

\begin{abstract}
Emerging infectious diseases threaten human and wildlife populations. Altered ecological interactions between mutualistic microbes and hosts can result in disease, but an understanding of interactions between host, microbes and disease-causing organisms may lead to management strategies to affect disease outcomes. Many amphibian species in relatively pristine habitats are experiencing dramatic population declines and extinctions due to the skin disease chytridiomycosis, which is caused by the chytrid fungus Batrachochytrium dendrobatidis. Using a randomized, replicated experiment, we show that adding an antifungal bacterial species, Janthinobacterium lividum, found on several species of amphibians to the skins of the frog Rana muscosa prevented morbidity and mortality caused by the pathogen. The bacterial species produces the anti-chytrid metabolite violacein, which was found in much higher concentrations on frog skins in the treatments where J. lividum was added. Our results show that cutaneous microbes are a part of amphibians' innate immune system, the microbial community structure on frog skins is a determinant of disease outcome and altering microbial interactions on frog skins can prevent a lethal disease outcome. A bioaugmentation strategy may be an effective management tool to control chytridiomycosis in amphibian survival assurance colonies and in nature.
\end{abstract}

The ISME Journal (2009) 3, 818-824; doi:10.1038/ismej.2009.27; published online 26 March 2009

Subject Category: microbe-microbe and microbe-host interactions

Keywords: Batrachochytrium dendrobatidis; bioaugmentation; chytridiomycosis; Rana muscosa; violacein

\section{Introduction}

Infectious diseases are emerging at an increasing rate (Daszak et al., 2000). Some of these diseases pose a direct threat to humans, such as HIV, whereas diseases of wildlife threaten global biodiversity and therefore indirectly affect human welfare. One reason that infectious diseases are emerging at a more rapid rate is that ecological relationships have been altered in ways that favor disease transmission (Daszak et al., 2000; Keesing et al., 2006). For example, changes in the geographic distribution of pathogens and hosts can lead to disease outbreaks,

Correspondence: RN Harris, Department of Biology, James Madison University, MSC 7801, Harrisonburg, VA 22807, USA. E-mail: harrisRN@jmu.edu

Received 27 January 2009; revised 23 February 2009; accepted 23 February 2009; published online 26 March 2009 as has occurred with West Nile virus (Allan et al., 2009). Alteration of the ecological structure of communities is also implicated in disease outbreaks. For example, the incidence of the bacterially caused Lyme disease in the human population increased when the relative abundance of alternative hosts declined (LoGiudice et al., 2003) and it may depend on the community structure of competitive microbes within tick vectors (Clay et al., 2006).

The community structure of microbes on and within hosts is associated with resistance to disease (Dethlefsen et al., 2007). For example, antifungal microbes can be important in disease resistance in a variety of species (Gil-Turnes et al., 1989; Gil-Turnes and Fenical, 1992; Currie et al., 1999; Kaltenpoth et al., 2005; Scarborough et al., 2005; Scott et al., 2008). Disruption of antifungal microbial communities is likely to lead to a breakdown of the protective effects of beneficial microbes and may 
lead to disease emergence (Dethlefsen et al., 2007; Belden and Harris, 2007). On a more positive note, methods to restore protective microbial communities may provide a way to manage wildlife diseases in nature.

An emerging infectious disease, chytridiomycosis, is a major factor responsible for extinction of amphibian species, one-third of which are threatened with extinction (Stuart et al., 2004; Lips et al., 2006; Skerratt et al., 2007). Caused by the chytrid species Batrachochytrium dendrobatidis (Bd), this skin disease is linked to population declines and extinctions of over 200 amphibian species in areas unaffected by habitat loss (Longcore et al., 1999; Skerratt et al., 2007). Since its description in 1999, we have learned a considerable amount about the pathogen's life history, physiology, population genetics, its responses to host immunity and how it causes death (Morehouse et al., 2003; Piotrowski et al., 2004; Berger et al., 2005; Rollins-Smith and Conlon, 2005; Morgan et al., 2007; Voyles et al., 2007; Woodhams et al., 2007a, b, 2008). Much less is known about how to control or manage the disease in nature. We propose that community interactions between amphibians' skin microbes and $\mathrm{Bd}$ can be manipulated in a way to enhance disease resistance in the sense of reducing the impact of the disease.

We have identified a number of cutaneous bacteria of amphibians that inhibit $\mathrm{Bd}$ in vitro and are likely to be a part of amphibians' innate immune system (Harris et al., 2006; Woodhams et al., 2007b). In addition, using a 'bacterial removal' experiment, we have shown that the naturally occurring cutaneous microbial community on red-backed salamanders, Plethodon cinereus, is a determinant of disease outcome (Becker and Harris, under review). In the current study, we establish a model for the use of microbes to protect individual amphibians against chytridiomycosis. We have previously shown that amphibian skin microbes produce antifungal metabolites that inhibit Bd (Brucker et al., 2008a, b). The bacterial species used in this study, Janthinobacterium lividum, produces the antifungal and anti-Bd metabolite violacein (Brucker et al., 2008b). The amphibian study species used was the mountain yellow-legged frog, Rana muscosa, from high elevation ponds in the Sierra Nevada mountains. Chytridiomycosis has caused population declines and extinctions of many populations of this frog species (Rachowicz et al., 2006). When Bd arrives in some populations, it causes near-total mortality of the population. However, populations that persist with the pathogen have a higher proportion of individuals with culturable antifungal bacterial isolates than populations that decline once $\mathrm{Bd}$ arrives (Woodhams et al., 2007b). Using a randomized and replicated experiment, we added an antiBd bacterial species, J. lividum, to the skins of R. muscosa, which resulted in reduced morbidity and mortality associated with chytridiomycosis.

\section{Materials and methods}

Thirty-one $R$. muscosa juveniles were obtained from a laboratory colony, raised from field-collected eggs, at the University of California, Berkeley. Each frog was placed into its own autoclaved plastic container containing approximately $200 \mathrm{ml}$ of Provosoli medium (Wyngaard and Chinnappa, 1982) and was randomly assigned a position on metal racks in a temperature-controlled room set at $17^{\circ} \mathrm{C}$ with a $12 \mathrm{~h}$ light cycle. Containers were cleaned with 10\% bleach and autoclaved twice a week. Each frog was fed five crickets weekly. Animal care protocols were approved by the University of California, Berkeley's and James Madison University's Animal Care and Use Committee.

We performed a replicated, randomized experiment with three groups of $R$. muscosa: (1) Bd, exposure to Bd zoospores; (2) bacteria, exposure to J. lividum and (3) Bacteria $+\mathrm{Bd}$, exposure to both J. lividum and $\mathrm{Bd}$ zoospores. Eighteen frogs were used in this experiment with the sample size for each treatment group being six frogs, with each frog in a separate container. There was no difference in mass among the three treatment groups at the beginning of the experiment (analysis of variance (ANOVA): d.f. $=2.15, \mathrm{~F}=0.943, P=0.411$ ). A preliminary experiment with another 10 juvenile $R$. muscosa was conducted to obtain a growth rate under standard laboratory conditions. This estimate was used as a comparison for growth rates estimated from the 18 frogs in the three manipulated treatment groups. Three other juveniles were used to estimate the concentration of violacein on individuals that were not subjected to any experimental manipulations.

On 22 January 2008, 18 individuals were treated with a $25 \mathrm{ml}$ solution of $3 \%$ hydrogen peroxide for $45 \mathrm{~s}$ and immediately rinsed with sterile Provosoli medium before returning to new containers. This procedure reduces the number of bacterial species on the skin, thereby minimizing community interactions between J. lividum and other cutaneous bacterial species. Therefore, we could standardize initial conditions on the frogs' skins and more readily attribute treatment effects to the presence or absence of J. lividum. After a period of $24 \mathrm{~h}$, each frog in the Bacteria and the Bacteria + Bd treatments was inoculated with J. lividum in individual containers. The J. lividum strain used was obtained from the skin of the salamander Hemidactylium scutatum collected in the George Washington National Forest, Rockingham Co., VA, USA. This strain was chosen because its anti-Bd metabolites violacein and indole-3-carboxaldehyde have been characterized (Brucker et al., 2008b). A pure culture of $J$. lividum was incubated for $72 \mathrm{~h}$ at room temperature in 1\% tryptone while being continuously stirred. The culture was then centrifuged at $4500 \mathrm{~g}$ for $10 \mathrm{~min}$. The supernatant was discarded and the pellet was resuspended in sterile Provosoli 
medium. The resulting solution was diluted to obtain a concentration of $26.25 \times 10^{6}$ cells per ml. Frogs were placed in autoclaved $120 \mathrm{ml}$ GladWare containers (Glad Products Co., Oakland, CA, USA) with $15 \mathrm{ml}$ of the bacterial solution for $30 \mathrm{~min}$. During this time, frogs in the $\mathrm{Bd}$ treatment were exposed to medium alone. Individuals were then placed into sterile containers for $48 \mathrm{~h}$ to allow J. lividum to establish on the skin of the inoculated frogs.

At this time, individuals in the $\mathrm{Bd}$ and the Bacteria $+\mathrm{Bd}$ treatments were exposed to $\mathrm{Bd}$ zoospores. This day was considered day 1 of the experiment. Immediately before the exposure, all frogs were weighed. Frogs were individually placed in $120 \mathrm{ml}$ GladWare containers with 300 zoospores suspended in $15 \mathrm{ml}$ of Provosoli medium for $24 \mathrm{~h}$. Alternatively, frogs in the Bacteria treatment were exposed to medium alone. The Bd strain JEL 215 isolated from $R$. muscosa was used for exposure. Cultures of the isolate were maintained in $1 \%$ tryptone and transferred weekly. The zoospore solution used to inoculate the frogs was prepared by growing zoospores on plates containing $1 \%$ tryptone and $1 \%$ agar. After a period of approximately $72 \mathrm{~h}$, the plates were flooded with $6 \mathrm{ml}$ of Provosoli medium. After $20 \mathrm{~min}$, the remaining solution was removed by pipette. The zoospore concentration was determined by a hemacytometer and diluted to 20 zoospores per $\mathrm{ml}$.

After Bd exposure and the initial weight measurement, frogs were weighed approximately every 2 weeks. Sampling for J. lividum and for Bd was completed on 29 January 2008 and approximately every 2 weeks after this date. After rinsing each individual in sterile Provosoli medium twice, frogs were swabbed 10 times on their ventral surface with a rayon swab (Medical Wire and Equipment, Corsham, Wiltshire, UK) on the dorsal surface of the abdomen, legs and feet to detect $\mathrm{Bd}$ presence and to estimate abundance. The same procedure was carried out to assay for the presence of J. lividum. Swabs were immediately frozen at $-20^{\circ} \mathrm{C}$ until further processing occurred. Swabs from 22, 61 and 139 days after exposure to $\mathrm{Bd}$ were sent to Pisces Molecular (Boulder, CO, USA) for DNA extraction and for an estimate of Bd abundance using TaqMan PCR. Swabs from days 5, 19, 47 and 139 were assayed for the presence of $J$. lividum using PCR. DNA was extracted from the swabs using a Qiagen DNeasy Blood and Tissue kit (Germantown, MD, USA) with the manufacturer's protocol. DNA obtained from the swabs was amplified using the $J$. lividum-specific primers JlivF (5'-TACCACGAATTGCTGTGCCAGTTG-3') and JlivR (5'-ACACG CTCCAGGTATACGTCTTCA-3'). These primers were designed using the J. lividum strain SKVTC8 violacein pigment gene obtained from GenBank (accession no. EU732703.1). PCR reactions (35 $\mu$ l) contained $0.2 \mu \mathrm{M}$ of each primer, $0.2 \mathrm{mM}$ dNTPs, $2.5 \mathrm{U}$ Taq polymerase with $1 \times$ buffer $(1.5 \mathrm{mM}$ $\mathrm{MgCl}_{2}, 50 \mathrm{mM} \mathrm{KCl}, 10 \mathrm{mM}$ Tris; Fisher Scientific,
Pittsburg, PA, USA). The amplification conditions were as follows: $4 \mathrm{~min}$ at $94^{\circ} \mathrm{C}$ followed by 35 cycles of $30 \mathrm{~s}$ at $94{ }^{\circ} \mathrm{C}, 60 \mathrm{~s}$ at $60^{\circ} \mathrm{C}$ and $2 \mathrm{~min}$ at $72^{\circ} \mathrm{C}$. The amplification was completed with a final extension for $10 \mathrm{~min}$ at $72{ }^{\circ} \mathrm{C}$. DNA from a pure culture of $J$. lividum, which was the same strain used in the experiment, was extracted with a MoBio Microbial Ultra Clean DNA kit (Carlsbad, CA, USA) and amplified along with extracted swabs to act as a positive control. The amplification products were separated by electrophoresis through $2 \%$ agarose and stained with ethidium bromide $\left(5 \mu \mathrm{g} \mathrm{ml}^{-1}\right)$. Presence or absence of a band around $500 \mathrm{bp}$ was determined for each swab using ultraviolet light. On the 140th day of the experiment (12 June 2008), frogs were killed with carbon dioxide. The concentration of violacein on the skin was determined according to the method of Brucker et al. (2008b).

Differences in means were tested with ANOVA unless data were not normally distributed, in which case a nonparametric Wilcoxon test was used. A repeated-measures ANOVA was used to test for differences in the number of zoospores over time as a function of treatment. One value for zoospore equivalents in the Bacteria treatment was an extreme outlier (Dixon's test: $r_{10}=1.0, \quad n=6$, $P<0.01$ ) and was not considered in the analysis. Frequency differences were tested with Fisher's exact test, and survival differences were tested with a Mantel-Cox log-rank test.

\section{Results}

Application of anti-Bd bacteria to uninfected frogs Placing frogs into a solution with J. lividum led to successful colonization of the skin. Primers specific to $J$. lividum indicated that all individuals in the experiment had J. lividum on their skins, whether or not they were exposed to a bath of this bacterial species. However, the metabolite produced by $J$. lividum, violacein, was found only on the frogs bathed in the J. lividum solution (see below), whereas frogs not treated had no detectable violacein on their skins. This result suggests that bathing in J. lividum increased population densities to the point where the secondary metabolite violacein was produced.

\section{Survival}

Adding $J$. lividum to uninfected frogs prevented lethal effects of the disease (Figure 1a). Five of six frogs in the Bd treatment died, and the sixth frog displayed symptoms of advanced-stage chytridiomycosis. No mortality occurred in the Bacteria and the Bacteria $+\mathrm{Bd}$ treatments (Mantel-Cox log-rank test: d.f. $\left.=2, \chi^{2}=15.877, P=0.0004\right)$.

\section{Change in weight}

Frogs in the Bd treatment did not grow and lost some weight on average (Figure 1b). Frogs that were 

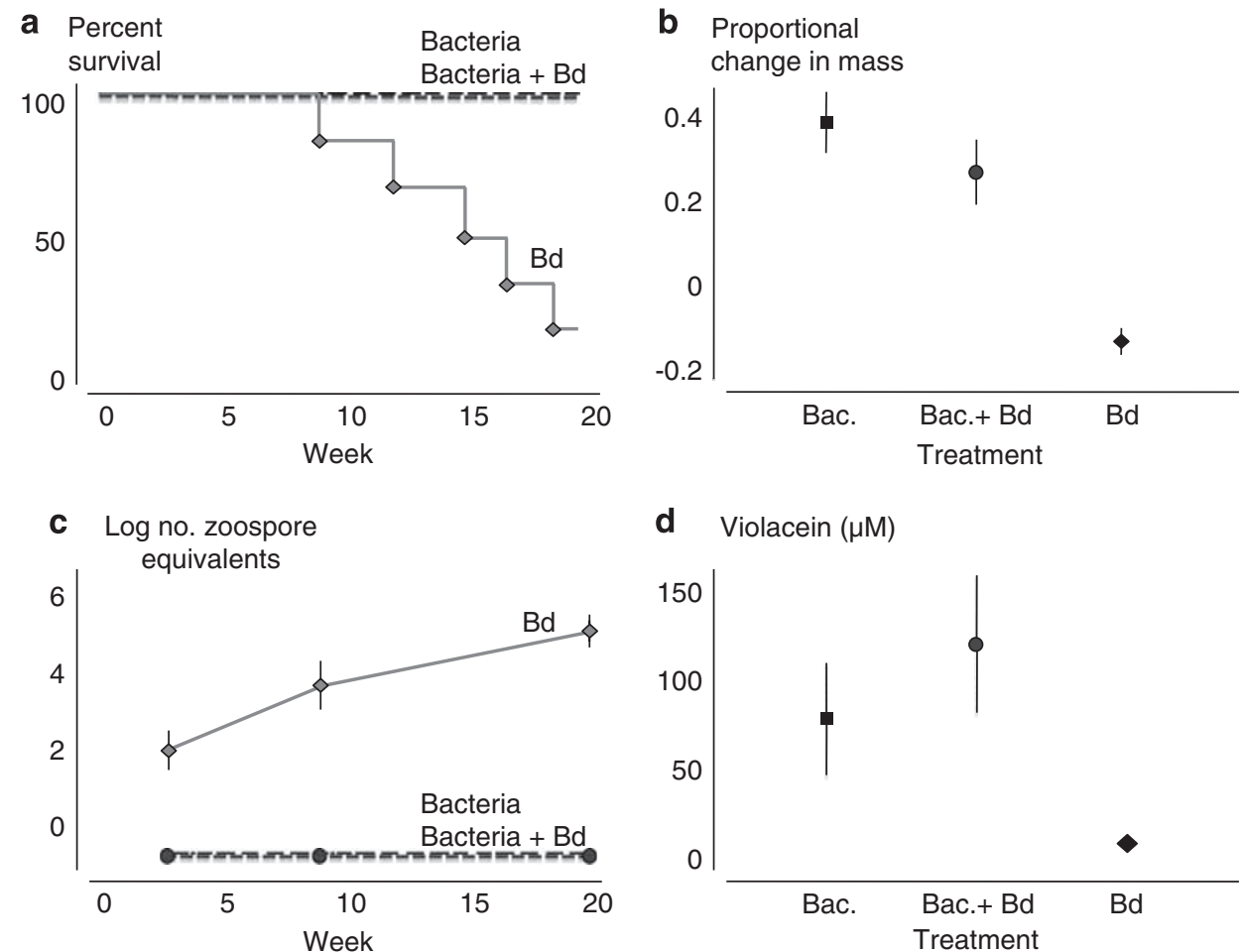

Figure 1 The effect of treatment group on (a) survival, (b) proportional growth of frogs, (c) the mean number of zoospore equivalents of B. dendrobatidis and (d) violacein concentration on frog skins. Error bars represent +1 s.e. (black, Bacteria treatment; green, Bacteria + Bd treatment; orange, $\mathrm{Bd}$ treatment). A full colour version of this figure is available at The ISME Journal online.

inoculated with $J$. lividum or that were inoculated with J. lividum before exposure to $\mathrm{Bd}$ grew and gained about $33 \%$ of body mass (ANOVA: d.f. $=2.15, F=17.71, P=0.0001)$. Frogs in these later two treatments had a daily growth rate that was the same as the growth rate of 10 unmanipulated frogs in a preliminary experiment (see Materials and methods, ANOVA: d.f. $=2.19$, $\mathrm{F}=0.81, P=0.461$ ), suggesting that bacteria addition alone did not affect growth rate and that bacterial addition before exposure to Bd prevented weight loss that was associated with Bd infection.

\section{Bd abundance}

The number of zoospore equivalents measured by qPCR is an index of $\mathrm{Bd}$ abundance. Zoospore equivalents on frogs in the Bd treatment increased exponentially as the experiment progressed (Figure 1c). Frogs in the Bacteria and the Bacteria $+\mathrm{Bd}$ treatments had no detectable zoospore equivalents on their skins from the day of the first sample (day 19) until our last sample (day 139), which was a dramatic difference from the Bd treatment (repeatedmeasures ANOVA for the treatment $\times$ time interaction: d.f. $=4.28$, Wilks' $\lambda=0.179, \quad P=0.0001$ ). Furthermore, the bacteria added to frog skins in the Bacteria $+\mathrm{Bd}$ treatment prevented successful establishment by $\mathrm{Bd}$ zoospores (Kruskal-Wallis test-day 19: d.f. $=2, \chi^{2}=12.645, P=0.013$; day 62 : d.f. $=2, \chi^{2}=16.129, P=0.0003$ and day 139: d.f. $=2$, $\chi^{2}=16.129, P=0.0003$ ).

\section{Violacein}

Survival of frogs was strongly associated with presence of violacein, an anti-Bd metabolite produced by J. lividum (Figure 1d). The five frogs that died in the Bd treatment had no detectable violacein concentration on their skin. The frog that survived in the $\mathrm{Bd}$ treatment did not have detectable quantities of violacein $(<5 \mu \mathrm{M})$; however, its weight loss, zoospore load and lethargic behavior indicated serious Bd infection. The mean violacein concentrations were much higher on frog skins in the Bacteria and the Bacteria $+\mathrm{Bd}$ treatments than in the $\mathrm{Bd}$ treatment (Figure 1d; Kruskal-Wallis test: d.f. $=2$, $\left.\chi^{2}=8.727, P=0.018\right)$. The three juveniles that were not exposed to J. lividum or $\mathrm{Bd}$ had no detectable violacein concentration on their skins.

\section{Discussion}

We found that morbidity and mortality caused by Bd were prevented by bioaugmentation of frog skins with $J$. lividum and conclude that ecological interactions between resident microbes and colonizing pathogens are an important component of their innate immunity. There is an increasing awareness 
that in many species microbial community composition of a host individual can determine disease outcome once a pathogen colonizes (Belden and Harris, 2007; Dethlefsen et al., 2007; Ostfeld et al., 2008). In addition, microbial interactions in disease vectors can affect pathogen prevalence and disease (Clay et al., 2006). It is becoming clear that to understand disease dynamics, the interactions between the host, its resident microbes and colonizing pathogens need to be characterized.

In this experiment, we exposed juvenile frogs to a low concentration of $\mathrm{Bd}$ zoospores relative to most other investigators (Rachowicz et al., 2006; Retallick and Miera, 2007; Woodhams et al., 2007a). However, the concentration of zoospores we used was higher than that estimated from pond water in nature (Kirshtein et al., 2007; Walker et al., 2007). For example, Kirshtein et al., 2007 and Walker et al., 2007 estimated that zoospore density in ponds varied from 0.5 to 454 zoospores per liter, whereas our exposure protocol was 20000 zoospores per liter for $24 \mathrm{~h}$. A sampling of recent experimental papers reveals that individual amphibians were exposed to Bd densities in their experimental containers that ranged from 25000 zoospores per liter (Rachowicz and Vredenburg, 2004) to $10^{5}-10^{6}$ zoospores per liter (Rachowicz et al., 2006; Retallick and Miera, 2007; Woodhams et al., 2007a). Further experimentation that varies level and duration of exposure to $\mathrm{Bd}$ zoospores in relation to population densities of anti$\mathrm{Bd}$ bacteria is needed to determine under what conditions the cutaneous microbiota are protective.

Our experiment tested whether bacterial residents from one species can effectively colonize another species. We used J. lividum isolated from a salamander species to inoculate juvenile frogs used in this experiment. We have found J. lividum on R. muscosa, suggesting that J. lividum is a resident microbe and that $J$. lividum from another amphibian species can be used to augment its density (Woodhams et al., 2007b). In addition, we had completed a study of anti-Bd metabolites produced by this strain, so the reduction in morbidity and mortality caused by $\mathrm{Bd}$ can be linked to its metabolites (Brucker et al., 2008b). Our results suggest that we will have the potential to target the broader susceptible amphibian community if bioaugmentation as a way to control $\mathrm{Bd}$ moves from the laboratory to field environments.

The metabolite violacein inhibits $\mathrm{Bd}$ at a low concentration in vitro (Brucker et al., 2008b) and is produced by J. lividum and not by amphibians. This metabolite is produced by other bacterial species as well and has a protective function (Yang et al., 2007; Matz et al., 2008). Analysis of violacein on wild caught salamanders has shown concentrations on skins high enough to inhibit Bd (Brucker et al., 2008b). Because bacteria generally do not produce antifungal secondary metabolites such as violacein until population densities are high, we suggest that in our experiment J. lividum was present at high population densities on frog skins. Amphibians may be able to regulate microbial community structure on their skins by their secretion of antimicrobial peptides, which are produced in granular glands (Rollins-Smith and Conlon, 2005). It is a question for future research to determine if this regulation occurs and if it acts in a way to increase selectively the growth of skin bacterial strains that produce antibiotic metabolites when the amphibian is exposed to skin pathogens.

Our results suggest that bioaugmentation with suitable anti-Bd bacteria can be used to prevent $\mathrm{Bd}$ infections in survival assurance or captive breeding colonies of amphibian species. These colonies are an important component of conservation efforts, especially if individuals can be re-introduced into the wild. A barrier to re-introduction is that invariably one or more amphibian species in their natural habitats are resistant to $\mathrm{Bd}$ and serve as reservoirs (Mendelson et al., 2006; Young et al., 2007). Treatment of susceptible amphibian species with antifungal skin bacteria may allow reintroduced individuals to coexist with $\mathrm{Bd}$ in native habitats. In this context, it is important to estimate how long bacterial treatments work after release of treated amphibians into the wild. We found violacein on frogs at the end of the experiment 20 weeks after bacterial inoculation, which suggests that the effects of bioaugmentation last at least that long.

Amphibians as a group are facing large population declines and extinctions due to chytridiomycosis, which makes research into management and prevention a high priority for amphibian conservation biologists. Our results demonstrate that an understanding of the community ecology of amphibian skins is a key component of attempts to control this emerging infectious disease. A simple manipulation of amphibians' cutaneous microbial community is a promising management tool to treat infected individuals. In addition, previous work has shown that populations of $R$. muscosa that coexist with Bd had a higher proportion of individuals with at least one anti-Bd isolate of skin bacteria (Woodhams et al., 2007b; unpublished data). Treatment of individual frogs may allow populations to achieve a higher proportion of individuals with protective bacteria and therefore allow coexistence with the pathogen.

There are a number of questions for future research that should be addressed before bioaugmentation is considered in natural settings. One important question is whether bioaugmentation is effective without first reducing frogs' cutaneous microbiota. We have shown in another laboratory study that bioaugmentation of salamander skins without first reducing resident microbiota did ameliorate the symptoms of chytridiomycosis, which is encouraging (Harris et al., 2009). A bioaugmentation protocol in nature has the potential to be self-disseminating after initial treatment. However, it is critical to understand any effects bioaugmentation might have on nontarget 
species. One way to minimize such effects is to add skin bacteria already found on at least some frogs in the population to increase the proportion of individuals with anti-Bd bacteria. Indeed, we have found $J$. lividum on $R$. muscosa (Woodhams et al., 2007b). We note that bacterial additions in agricultural contexts are effective in controlling disease and do not negatively affect nontarget species (Berg et al., 2007; Scherwinski et al., 2008), which is encouraging. Whether to adopt a bioaugmentation strategy to control chytridiomycosis in nature presents a challenging ecological dilemma. The decisionmaking process can benefit from the framework of ecological ethics (Minteer and Collins, 2008), which balances the duties and risks to various entities including amphibians, ecosystems and public welfare. In sum, additional research on the relationship of amphibians' skin microbes and Bd is urgently needed to assess the efficacy of bioaugmentation as a control strategy for $\mathrm{Bd}$.

\section{Acknowledgements}

We thank G Wyngaard and J Kastendiek for valuable comments on the paper, J Wood for PCR analysis and M Toothman for technical support. Permits to collect were provided by the California Department of Fish and Game and the National Park Service. Animal care protocols were approved by UC Berkeley's and JMU's Animal Care and Use Committee. This work was supported by a Research Corporation Cottrell College Science Award (KPCM), the Thomas F Jeffress and Kate Miller Jeffress Memorial Trust (KPCM), a National Science Foundation grant 0640373 (RNH) and James Madison University.

\section{References}

Allan BF, Langerhans RB, Rybert WA, Landesman WJ, Griffin NW, Katz RS et al. (2009). Ecological correlates of risk and incidence of West Nile virus in the United States. Oecologia 158: 699-708.

Belden LK, Harris RN. (2007). Infectious diseases in wildlife: the community ecology context. Front Ecol Environ 5: 533-539.

Berg G, Grosch R, Scherwinski K. (2007). Risikofolgeabschätzung für den Einsatz mikrobieller Antagonisten: Gibt es Effekte auf Nichtzielorganismen? Gesunde Pflanzen 59: 107-117.

Berger L, Hyatt AD, Speare R, Longcore JE. (2005). Life cycle stages of the amphibian chytrid Batrachochytrium dendrobatidis. Dis Aquat Org 68: 51-63.

Brucker RM, Baylor CM, Walters RL, Lauer A, Harris RN, Minbiole KPC et al. (2008a). The identification of 2,4-diacetylphloroglucinol as an antifungal metabolite produced by cutaneous bacteria of the salamander Plethodon cinereus. J Chem Ecol 34: 39-43.

Brucker RM, Harris RN, Schwantes CR, Gallaher TN, Flaherty DC, Lam BA et al. (2008b). Amphibian chemical defense: antifungal metabolites of the micro- symbiont Janthinobacterium lividum on the salamander Plethodon cinereus. J Chem Ecol 34: 1422-1429.

Clay K, Fuqua C, Lively C, Wade MJ. (2006). Microbial community ecology of tick-borne human pathogens. In: Collinge SK, Ray C (eds). Disease Ecology: Community Structure and Pathogen Dynamics. Oxford University Press: Oxford. pp 41-57.

Currie CR, Scott JA, Summerbell RC, Malloch D. (1999). Fungus-growing ants use antibiotic-producing bacteria to control garden parasites. Nature 398: 701-704.

Daszak P, Cunningham AA, Hyatt AD. (2000). Emerging infectious diseases of wildlife: threats to biodiversity and human health. Science 287: 443-449.

Dethlefsen L, McFall-Ngai M, Relman DA. (2007). An ecological and evolutionary perspective on humanmicrobe mutualism and disease. Nature 449: 811-818.

Gil-Turnes MS, Fenical W. (1992). Embryos of Homarus americanus are protected by epibiotic bacteria. Biol Bull 182: 105-108.

Gil-Turnes MS, Hay ME, Fenical W. (1989). Symbiotic marine bacteria chemically defend crustacean embryos from a pathogenic fungus. Science 246: 116-118.

Harris RN, James TY, Lauer A, Simon MA, Patel A. (2006). Amphibian pathogen Batrachochytrium dendrobatidis is inhibited by the cutaneous bacteria of amphibian species. EcoHealth 3: 53-56.

Harris RN, Lauer A, Simon MA, Banning JL, Alford RA. (2009). Addition of antifungal skin bacteria to salamanders ameliorates the effects of chytridiomycosis. Dis Aquat Org 83: 11-16.

Kaltenpoth M, Gottler W, Herzner G, Strohm E. (2005). Symbiotic bacteria protect wasp larvae from fungal infestation. Curr Biol 15: 475-479.

Keesing F, Holt RD, Ostfeld RS. (2006). Effects of species diversity on disease risk. Ecol Lett 9: 485-498.

Kirshtein JD, Anderson CW, Wood JS, Longcore JE, Voytek MA. (2007). Quantitative PCR detection of Batrachochytrium dendrobatidis DNA from sediments and water. Dis Aquat Org 77: 11-15.

Lips KR, Brem F, Brenes R, Reeve JD, Alford RA, Voyles J et al. (2006). Emerging infectious disease and the loss of biodiversity in a neotropical amphibian community. Proc Natl Acad Sci USA 102: 3165-3170.

LoGiudice K, Ostfeld RS, Schmidt KA, Keesing F. (2003). The ecology of infectious disease: effects of host diversity and community composition on Lyme disease risk. Proc Natl Acad Sci USA 100: 567-571.

Longcore JE, Pessier AP, Nichols DK. (1999). Batrachochytrium dendrobatidis gen. et sp. nov., a chytrid pathogenic to amphibians. Mycologia 9: 219-227.

Matz C, Webb JS, Schupp PJ, Phang SY, Penesyan A, Egan $S$ et al. (2008). Marine biofilm bacteria evade eukaryotic predation by targeted chemical defense. PLOS ONE 3: e2744. doi:10.1371/journal.pone.0002744.

Mendelson JR, Lips KR, Gagliardo RW, Rabb GB, Collins JP, Diffendorfer JE et al. (2006). Confronting amphibian declines and extinctions. Science 313: 48.

Minteer BA, Collins JP. (2008). From environmental to ecological ethics: toward a practical ethics for ecologists and conservationists. Sci Eng Ethics 14: 483-501.

Morehouse EA, James TY, Ganley ARD, Vilgalys R, Berger L, Murphy PJ et al. (2003). Multilocus sequence typing suggests the chytrid pathogen of amphibians is a recently emerged clone. Mol Ecol 12: 395-403.

Morgan JA, Vredenburg VT, Rachowicz LJ, Knapp RA, Stice MJ, Tunstall T et al. (2007). Population genetics 
of the frog-killing fungus Batrachochytrium dendrobatidis. Proc Natl Acad Sci USA 104: 13845-13850.

Ostfeld RS, Keesing F, Eviner VT (eds) (2008). Infectious Disease Ecology: Effects of Ecosystems on Disease and of Disease on Ecosystems. Princeton University Press: Princeton.

Piotrowski JS, Annis SL, Longcore JE. (2004). Physiology of Batrachochytrium dendrobatidis, a chytrid pathogen of amphibians. Mycologia 96: 9-15.

Rachowicz LJ, Knapp RA, Morgan JAT, Stice MJ, Vredenburg VT, Parker JM et al. (2006). Emerging infectious disease as a proximate cause of amphibian mass mortality. Ecology 87: 1671-1683.

Rachowicz LJ, Vredenburg VT. (2004). Transmission of Batrachochytrium dendrobatidis within and between amphibian life stages. Dis Aquat Org 61: 75-83.

Retallick RWR, Miera V. (2007). Strain differences in the amphibian chytrid Batrachochytrium dendrobatidis and non-permanent, sub-lethal effects of infection. Dis Aquat Org 75: 201-207.

Rollins-Smith LA, Conlon JM. (2005). Antimicrobial peptide defenses against chytridiomycosis, an emerging infectious disease of amphibian populations. Dev Comp Immunol 29: 589-598.

Scarborough CL, Ferrari J, Godfray HCJ. (2005). Aphid protected from pathogen by endosymbiont. Science 310: 1781.

Scherwinski K, Grosch R, Berg G. (2008). Effect of bacterial antagonists on lettuce: active biocontrol of Rhizoctonia solani and negligible, short-term effects on nontarget microorganisms. FEMS Microbiol Ecol 64: 106-116.

Scott JJ, Oh D, Yuceer MC, Klepzig KD, Clardy J, Currie CR. (2008). Bacterial protection of beetle-fungus mutualism. Science 322: 3.

Skerratt LF, Berger L, Speare R, Cashins S, McDonald KR, Phillott AD et al. (2007). Spread of chytridiomycosis has caused the rapid global decline and extinction of frogs. EcoHealth 4: 125-134.
Stuart SN, Chanson JS, Cox NA, Young BE, Rodrigues ASL, Fischman DL et al. (2004). Status and trends of amphibian declines and extinctions worldwide. Science 306: 1783-1786.

Voyles J, Berger L, Young S, Speare R, Webb R, Warner J et al. (2007). Electrolyte depletion and osmotic imbalance in amphibians with chytridiomycosis. Dis Aquat Org 77: 113-118.

Walker SF, Salas MB, Jenkins D, Garner TWJ, Cunningham AA. (2007). Environmental detection of Batrachochytrium dendrobatidis in a temperate climate. Dis Aquat Org 77: 105-112.

Woodhams DC, Alford RA, Briggs CJ, Johnson M, Rollins-Smith LA. (2008). Life-history trade-offs influence disease in changing climates: strategies of an amphibian pathogen. Ecology 89: 1627-1639.

Woodhams DC, Ardipradja K, Alford RA, Marantelli G, Reinert LK, Rollins-Smith LA. (2007a). Resistance to chytridiomycosis varies among amphibian species and is correlated with skin peptide defenses. Anim Conserv 10: 409-417.

Woodhams DC, Vredenburg VT, Simon MA, Billheimer D, Shakhtour B, Shyr Y et al. (2007b). Symbiotic bacteria contribute to innate immune defenses of the threatened mountain yellow-legged frog, Rana muscosa. Biol Conserv 138: 390-398.

Wyngaard GA, Chinnappa CC. (1982). General biology and cytology of cyclopoids. In: Harrison FW, Cowden RR (eds). Developmental Biology of Freshwater Invertebrates. AR Liss: New York, pp 485-533.

Yang LH, Xiong H, Lee OO, Qi SH, Qian PY. (2007). Effect of agitation on violacein production in Pseudoalteromonas luteoviolacea isolated from a marine sponge. Lett Appl Microbiol 44: 625-630.

Young S, Berger L, Speare R. (2007). Amphibian chytridiomycosis: strategies for captive management and conservation. Int Zoo Yb 41: 1-11. 